Boston University School of Law Scholarly Commons at Boston University School of Law

Faculty Scholarship

$10-2018$

\title{
The Law Officer (LO) and Compliance Officer (CO): Status, Function, Liabilities, and Relationship
}

Tamar Frankel

Boston University School of Law

Follow this and additional works at: https://scholarship.law.bu.edu/faculty_scholarship

Part of the Law and Economics Commons

\section{Recommended Citation}

Tamar Frankel, The Law Officer (LO) and Compliance Officer (CO): Status, Function, Liabilities, and Relationship, No. 18-25 Boston University School of Law, Law and Economics Research Paper (2018).

Available at: https://scholarship.law.bu.edu/faculty_scholarship/413 


\title{
BU School of Law
}

\section{THE LAW OFFICE (LO) AND COMPLIANCE OFFICER (CO): STATUS, FUNCTION, LIABILITIES, AND RELATIONSHIP}

\author{
Boston University School of Law \\ Law \& Economics Series Paper No. 18-25
}

October 2018

Tamar Frankel

Boston University School of Law 


\section{The Law Officer (LO) and Compliance Officer: (CO): Status, Function, Liabilities; and Relationship \\ Tamar Frankel ${ }^{1}$}

Introduction. The rise of Compliance officers (COs) has raised questions about their status in institutions and comparisons to the Legal Officers (CLOs). While both officers deal with law and its enforcement, their functions and positions differ in fundamental ways. And while LOs position is recognized, the status of COs is evolving. However, these differences are slowly becoming clearer.

1. While the LO's function is to provide legal advice to the institutional client, the CO's function is to (i) evaluate the institution's activities before violations take place and (ii) help prevent violations of the law by the institution. The CO should detect and help prevent institutional violations, avoiding the need to defend the client. Therefore, COs and LOs might focus on different issues and provide different advice to clients.

a. The focus of LO and CO service may differ. The LO might focus on legal gaps, through which clients may act free of legal constraints, and strive to protect the client after it may have violated the law. In contrast, the CO analyzes the law, and recommends steps to avoid the risk of future violations of current legal activities, putting business interests or short term objectives in second place. Thus, the COs and LOs offer management a somewhat different service addressing different concerns. Legal risks require the CO to tell management what they should not do, while the LO tells management what they can do. The services of the LO can be viewed as enabling, while the services of the $\mathrm{CO}$ can be viewed as more limiting the freedom to act. The COs should be knowledgeable in the law. ${ }^{2}$ However, they should also focus on "Should I do this?" rather than "Can I do this?" and "constantly challeng[e] [themselves] and [their] colleagues to identify potential risks."”

\footnotetext{
${ }^{1}$ Tamar Frankel, Professor of Law Emerita, Boston University School of Law. This note is derived mostly from Tamar Frankel, Institutional Self Regulation (Compliance) Chapter 17 (2018).

${ }^{2}$ Andrew J. Donohue, Remarks at NRS 30th Annual Fall Investment Adviser and Broker-Dealer Compliance Conference (San Diego, Cal., Aug. 14, 2015), available at https://www.sec.gov/news/speech/donohue-nrs-30th-annual.html (last visited Feb. 2, 2017). ${ }^{3}$ Id.
} 
b. Arguably, LO's and CO's allegiance to their institution differs. A LO acts in the best interests of the client ${ }^{45}$ and indirectly, including officers, directors, employees, shareholders, who benefit from the well-being of the company. ${ }^{6}$ If the client's interest conflict with that of a constituent, the lawyer does not represent the constituent. ${ }^{7}$

c. The CO may be responsible to other constituencies, although this responsibility is unclear. The SEC compliance- program rules applicable to investment companies and advisers require a CO to administer a firm's compliance policies. ${ }^{8}$ However, the SEC and personnel have suggested a measure of the CO's responsibility to other constituencies as well. The CO's duties are "designed to protect investors by ensuring that all funds and advisers have internal programs to enhance compliance with the federal securities laws."9

\section{d. Compliance personnel are viewed as critical to the integrity of the securities} markets," 10 required to serve as the customer's advocates." 11 The SEC Chairperson noted that compliance professionals "have the obligation to provide investors with an added measure of security above and beyond that which a regulator provides” by the SEC. ${ }^{12}$ Unlike LOs, that focus on the client's interests COs are legally required

4 See Model Code OF PROF'L RESPONSIBILITY EC 7-9 (1981).

${ }^{5}$ Model Rules of Prof’́ Conduct Rule 1.13(a) (2011).

${ }^{6}$ See Model Rules OF PROF’ L CONDUCT Rule 1.13(a) cmt. 1 (2011).

${ }^{7}$ See Model Rules of Prof’́ C CONDUCT Rule 1.13(a) cmt. 10 (2011).

8 17 C.F.R. § 270.38a-1(a)(4) (2016) (investment companies); 17 C.F.R. § 275.206(4)-7(c) (2016) (investment advisers).

${ }^{9}$ Compliance Programs of Investment Companies and Investment Advisers, IA-2204, IC-26299 (Dec. 17, 2003), 68 Fed. Reg. 74,714, 74,714 (Dec. 24, 2003) (emphasis added).

${ }^{10}$ Richard Y. Roberts, The Role of Compliance Personnel (National Regulatory Services 10th Anniversary Investment Adviser \& Broker-Dealer Compliance Conference, Paget Parish, Bermuda, Apr. 7, 1995), available at http://www.sec.gov/news/speech/speecharchive/1995/spch030.txt (last visited Apr. 9, 2016).

${ }^{11}$ John H. Walsh, Speech by SEC Staff: What Makes Compliance a Profession? (NRS Symposium on the Compliance Profession, Miami Beach, Apr. 11, 2002), available at http://www.sec.gov/news/speech/spch558.htm (last visited Apr. 9, 2016).

\footnotetext{
${ }^{12}$ Mary L. Schapiro, Speech by SEC Chairman:Remarks at the CCOutreach National Seminar (Washington, D.C., Jan. 26, 2010), available at https://www.sec.gov/news/speech/2010/spch012610mls.htm (last visited Sept. 25, 2016).
} 
to act in preventing the client's violations of the law Thus, while LOs have one client the CO may have responsibility to society as well, even though there is no statutory basis for this opinion. ${ }^{13}$

\section{The Unclear Differences and Relationship}

a. LOs and COs differ. Law has long been a special profession, subject to a formal ethical code, regardless of how some of them behave. ${ }^{14}$ In contrast compliance is an emerging profession that has been recognized as a profession only recently. ${ }^{15}$

\section{b. The LO and CO relationship is evolving and not necessarily smoothly. Their} views of their services may differ. Improving a compliance program might benefit the corporation's by reducing its legal risks, and, indirectly, the risks of its investors, and perhaps indirectly, the risks of the corporation's customers, if they relied on the corporation. But, short-term business considerations may prevail.

c. CO's rising importance and autonomy. Regulators such as the SEC have noted the importance of CO. The SEC stated that a "[CO] should be empowered with full responsibility and authority to develop and enforce appropriate policies and procedures for the firm. "COs will usually be a member of the senior management of a firm." ${ }^{16}$ In addition, this SEC staff member noted that while the CO is not explicitly required to report to the corporation's CEO, "if other ' $\mathrm{C}$ ' level executives (e.g., CFO, CIO) report directly to the CEO and the CCO does not, ... . [the SEC] staff may interpret this difference in reporting structure to mean that compliance is

\footnotetext{
${ }^{13}$ William H. Donaldson, Speech by SEC Chairman: Remarks Before the Mutual Fund and Investment Management Conference (Palm Desert, Cal., Mar. 14, 2005), available at

https://www.sec.gov/news/speech/spch031405whd.htm (last visited Feb. 2, 2017) (stating that new
} CCO outreach program “is not an effort to 'deputize’ CCOs as agents of the SEC”).

14 See, e.g., Roscoe Pound, The Professions in Society Today, NEw EngLAND J. OF MEDICINE, Sept. 8, 1949, at 351-53, cited in TAMAR FRANKEL, TRUST AND HONESTY 136-37 (2005); Roscoe Pound, THE LAWYER FROM ANTIQUITY TO MODERN TIMES 4-5, 9, 10 (1953), cited in TAMAR FRANKEL, TRUST AND HONESTY 137 (2005).

${ }^{15}$ Kara M. Stein, Keynote Address at Compliance Week 2014 (Washington, D.C., May 19, 2014), available at https://www.sec.gov/News/Speech/Detail/Speech/1370541857558 (last visited Feb. 2, 2017) (“The CCO is a relatively new position, and the role has evolved significantly over time”).

${ }^{16}$ Gene Gohlke, Speech by SEC Staff: Managed Funds Association Educational Seminar Series 2005: Practical Guidance for Hedge Fund CCOs Under the SEC's New Regulatory Framework (New York, N.Y., May 5, 2005), available at https://www.sec.gov/news/speech/spch050505gg.htm (last visited Feb. 2, 2017). 
not as important as those other functions and the ability of the CCO to compel compliance may be weakened."

d. The CO's authority and is expanding is evidencing. The, as is demonstrated by the Corporate Integrity Agreement entered into between Pfizer, Inc., and the Office of Inspector General of the Department of Health and Human Services. ${ }^{17}$ This agreement required that the CO report directly to the CEO and the board of directors' Audit Committee and specifically prohibited the CO from being subordinate to the LO. ${ }^{18}$ The agreement provided that the CO should have the same power level as the LO. In connection with the agreement, OIG's Chief Counsel Lewis Morris noted that the separation of the LO and CO would "eliminate conflicts of interest, and prevent Pfizer's in-house lawyers from reviewing or editing reports required by the agreement." ${ }^{19}$ This type of strict division may not reflect the general situation in 2017; yet it might point to the possible near future establishment of the $\mathrm{CO}$ as independent from the LO, as well as the increased management attention to the CO.

\section{Who Should Have the Final Say?}

a. When the facts in a particular transaction are unclear or controversial, how should a decision be made? Not only facts, but also rules can be vague, especially when applied to new situations. Such situations may arise often, especially as a result of innovations, and the entry of an institution into international relationships. In such situations, the CO's advice may differ and be stricter than that which might be offered by the LO.

b. The issue of confidentiality. Adding to the complexity of the LO-CO relationship is the fact that COs do not share with the LOs the ability to shelter their clients' information behind the veil of confidentiality. To be sure, the lawyer's duty to keep clients' information confidential is not absolute. In the case of an in-house attorney,

\footnotetext{
${ }^{17}$ Corporate Integrity Agreement Between the Office of Inspector General of the Department of Health and Human Services and Pfizer Inc., available at

http://oig.hhs.gov/fraud/cia/agreements/pfizer inc.pdf (last visited Aug. 5, 2014).

${ }^{18}$ Id. at 4.

${ }^{19}$ ETHISPHERE, THE BUSINESS CASE FOR CREATING A STANDALONE CHIEF COMPLIANCE OFFICER POSITION 6 (n.d.), available at http://m1.ethisphere.com/resources/whitepaper-separation-of-gc-and-cco.pdf (last visited Feb. 3, 2017).
} 
the client is the corporation. ${ }^{20}$ In addition, a lawyer may not assist a client in a conduct that the lawyer knows, is criminal or fraudulent. ${ }^{21}$ Further, unless ordered to continue representing a client before an appropriate tribunal, a lawyer must withdraw from representing a client if continuing to represent the client would result in a violation of the Model Rules or other laws. ${ }^{22}$ If a client plans to commit a crime associated with the lawyer's representation, the lawyer may withdraw from representation. ${ }^{23}$

\section{c. Under some circumstances, the lawyer may disclose confidential information regarding the client's plans to commit a crime?}

A lawyer may disclose confidential information relating to the representation of a client in limited circumstances, including: (1) "to prevent reasonably certain death or substantial bodily harm"; (2) "to prevent the client from committing a crime or perpetrating fraud that is reasonably certain to result in substantial injury to the financial interests or property of another and in furtherance of which the client has used or is using the lawyer's services"; (3) "to prevent, mitigate or rectify substantial injury to the financial interests or property of another that is reasonably certain to result or has resulted from the client's commission of a crime or fraud in furtherance of which the client has used the lawyer's services."24

\footnotetext{
${ }^{20}$ Model Rules of Prof’́ Conduct Rule 1.6 (2011).

${ }^{21}$ Model Rules of Prof’L ConduCt Rule 1.2(d) (2011).

${ }^{22}$ Model Rules of Prof'L Conduct Rule 1.16(a) (2011).
}

${ }^{23}$ A lawyer may withdraw from representation if "the client persists in a course of action involving the lawyer's services that the lawyer reasonably believes is criminal or fraudulent" (unless ordered to continue representation by a tribunal). MODEL RULES OF PROF'L Conduct Rule 1.16(b)(2) (2011). Similarly the lawyer may withdraw if "the client has used the lawyer's services to perpetrate a crime or fraud" (unless ordered to continue representation by a tribunal). MODEL RULES OF PROF'L CONDUCT Rule 1.16(b)(3) (2011). See also Jean Eaglesham, Wide Net Is Cast in Probe of Microcap, WALL ST. J., Aug. 15, 2014, at C1 ("The SEC is looking at whether some lawyers and accountants are liable for helping to enable penny-stock frauds, either by signing off on phony information or simply not asking the right questions ...”).

${ }^{24}$ Model Rules of Prof’L Conduct Rule 1.6(b)(1)-(3) (2011). 
In addition, a lawyer must disclose a material fact if necessary to avoid assisting a criminal or fraudulent act by a client, unless disclosure is otherwise prohibited by the confidentiality rules. ${ }^{25}$

\section{Under what circumstances is a LO, ethically obligated to "blow the whistle"} on their corporate client's misconduct? Ethical considerations under the Model Code provide that " $\mathrm{t}$ ] he attorney-client privilege is more limited than the ethical obligation of a lawyer to guard the confidences and secrets of his client”26 and that "[t]he obligation of a lawyer to preserve the confidences and secrets of his client continues after the termination of his employment."27 "Ethical obligations" mentioned in this paragraph include prohibitions of conflicts of interest as well as duties to offer qualified advice.

5. To be sure, compliance is a Profession. The opinion of Mr. John Walsh, when he served as Chief Counsel, Office of Compliance Inspections and Examinations at the $\mathrm{SEC}^{\mathbf{2 8}}$ is clear. While compliance is similar to litigation, as well as to in-house counseling, it is a different and separate profession. ${ }^{29} \mathrm{Mr}$. Walsh defined a profession by three features. First, a profession is "an occupation, for which the necessary training is intellectual, involving knowledge and learning as distinguished from skill." Second, a profession is "pursued largely" in the service of others. Third, the amount of financial rewards for the service is "not the accepted measure of success.” Compliance meets all three features.

\section{a. Compliance Requires a Significant Degree of Learning and Creativity}

\footnotetext{
${ }^{25}$ Model Rules of Prof’L Conduct Rule 4.1(b) (2011).

${ }^{26}$ Model Code of Professional Responsibility EC 4-4 (1980); H. Lowell Brown, The Dilemma of Corporate Counsel Faced with Client Misconduct: Disclosure of Client Confidences or Constructive Discharge, 44 BuFF. L. REV. 777, 795 (1996).

${ }^{27}$ Model Code of Professional Responsibility EC 4-6 (1980); H. Lowell Brown, The Dilemma of Corporate Counsel Faced with Client Misconduct: Disclosure of Client Confidences or Constructive Discharge, 44 BUFF. L. REV. 777, 795-96 (1996).

${ }^{28}$ John H. Walsh, Speech by SEC Staff: What Makes Compliance a Profession? (NRS Symposium on the Compliance Profession, Miami Beach, Apr. 11, 2002), available at

https://www.sec.gov/news/speech/spch558.htm (last visited Apr. 12, 2016).

${ }^{29}$ See also TERRANCE J. O’MALLEY \& JOHN H. WALSH, INVESTMENT ADVISER'S LEGAL AND COMPLIANCE GUIDE (2d ed. 2015).
} 
This service poses real demanding intellectual challenges. Regulating business is complex and changing. It applies to unpredictable situations. Compliance rules are usually stated as general duties, rather than bright-line directives. Therefore, they require interpretation and application to particular situations, often in unpredictable circumstances.

\section{b. In addition, understanding continuous changes that are taking place in the area of one's expertise is crucial to any profession. In the financial area, for} example, the laws since the 1940s were based on separate regulation of various species of intermediaries. These include: banks, credit unions, and similar organizations, brokers, exchanges, and other securities markets, mutual funds and advisers. The regulations of these various servicers and intermediaries addressed the characteristic problems that they posed. Throughout the years the functional boundaries between these intermediaries have been loosened. Functionalities and services were often combined or merged, and new intermediation (or disintermediation) structures have appeared. Most of these changes took place during the 1980's and 1990's. But they had effects for years thereafter.

Consequently, the task of a competent navigator of today's regulatory systems is a far more complex than it was in the past. Today's compliance office requires a high level of expertise as well. Compliance is a crucial and expanding profession.

c. Compliance is crucial in the United States system of securities regulation. Mr. Walsh noted that President Roosevelt took office during an economic crisis. Instead of controlling the securities industry, President Roosevelt "wanted the securities industry to be governed by 'a simple code of ethics' and "wanted to elevate its character, honesty, and honor," "Only when business was conducted in this fashion, only when the public's trust was morally justified, would confidence and prosperity return.” According to Mr. Walsh, "if there is any group in the modern securities industry that is ready to meet this ethical challenge, that is ready to establish and enforce a simple code, simple enough for the public to understand, it is compliance.”30

\footnotetext{
${ }^{30}$ John H. Walsh, Speech by SEC Staff: What Makes Compliance a Profession? (NRS Symposium on the Compliance Profession, Miami Beach, Apr. 11, 2002), available at

https://www.sec.gov/news/speech/spch558.htm (last visited Apr. 12, 2016).
} 
d. Like Medicine, Compliance Aims at Preventive Measures. Most compliance situations do not deal with violations that have occurred but with possible situations that may result in violations. While lawyers learn the law by focusing on specific cases that have already taken place, the compliance officer turns the process around, and looks at a rule to determine: How could "knowledgeable, imaginative, [and] creative people” attempt to violate this standard? As you read the law, you can imagine all the possible violations. Therefore, one must draw on expert judgment to find an effective answer. This is one feature of a professional.

\section{e. Compliance is similar to modern quality management: be "right the first} time," rather than catch and correct errors. In compliance one needs to take preventive actions, “designing and implementing preventive systems." In enforcement actions that present failure to supervise, "waiting for problems" is not an adequate approach. Both quality management and compliance must focus on becoming an integral part of the institution's routine and everyday operations: "training line employees" to "understand the difference" between "conforming and nonconforming output." "Education, training, and awareness are key elements.” These elements as well are the fundamental features of a profession. ${ }^{31}$

\section{f. A Profession Consists of Providing Service to Others. As Justice Brandeis} noted, a profession meets the needs of others: "Lawyers have clients. Doctors have patients." $32 \mathrm{Mr}$. Walsh suggested that compliance officers are the advocates of the business' customers, noting their complaints, examining and monitoring the advertising that targets them. Compliance officers can spot the danger and stop it before the customers suffer harm.

g. The focus of a profession is service, said Mr. Walsh; a measure of success in having achieved these objectives; not merely having made money. For compliance, this success is "quality” and "ethics." In the law, such services are in fact the service by fiduciaries. The two main duties of fiduciaries are the duty of care - expert

\footnotetext{
${ }^{31}$ John H. Walsh, Speech by SEC Staff: What Makes Compliance a Profession? (NRS Symposium on the Compliance Profession, Miami Beach, Apr. 11, 2002), available at

https://www.sec.gov/news/speech/spch558.htm (last visited Apr. 12, 2016).

32 Id., citing LOUIS DEMBITZ BRANDEIS, Business: A PROFESSION (1914).
} 
performance -- and the duty of loyalty - avoiding conflicts of interest. In essence, it means identifying with those whom you serve; putting yourself in their place.

Compliance must focus on flaws in the institutional structure and patterns of behavior. Like most management problems, most compliance failures have systemic causes. The more common causes include "misguided compensation," "unrealistic performance goals," and "uneven supervision." "By carefully monitoring for recurrent red flags, compliance can identify the firm's [underlying] structural flaws and fix them before serious harm [results]." "Every form of monitoring system, from sophisticated [suspicious activity] reports, to good old-fashioned customer complaints, can serve this purpose.”33

h. Even though "there is another way in which quality management and compliance are similar," this similarity is "less fortunate than the others." Business managers may treat "quality management" and compliance as "unproductive cost centers." "The literature [offers] examples of businesses that slashed quality [management] in an effort to [increase] short-term profits, only to find that they had [ultimately] destroyed the firm's long-term franchise." "Compliance is often in a similar predicament. If [viewed as a regulatory cost center and nothing else] it is a ready victim when the downsizing begins. For both quality [management] and compliance, part of [the] mission is to convince management that [they] add [significant and] substantial value to the competitiveness of the firm." Unfortunately, such convincing may take a "negative tone," recalling the significant problems that follow failures in quality management or compliance program. Evaluating risk is difficult because it promises returns, rather than losses. ${ }^{34}$

\section{i. As Noted, it is Compliance Rather than Management that Recognizes Risk.} Mr. Walsh suggests that management should also "recognize the [risk] it is running." To be sure, risk cannot be measured with precision. It should be balanced against gain. For example, management "should define customer satisfaction to include confidence in [the institutional] honesty and trustworthiness." Compliance and regulators "should ensure that full compliance is within the design specifications of

\footnotetext{
${ }^{33} \mathrm{Id}$.

${ }^{34} \mathrm{Id}$.
} 
the products and services [that the institution sells]." 35

This purpose leads to ethics which translated. legally into the fiduciary duty of loyalty--avoiding conflicting interests that undermine the relationship and trust of the customers. In this context, the duty of loyalty is far stricter than the same duty under corporate law. Here the duty prohibits service providers from accepting any benefit from a client without first disclosing any conflicts of interest and receiving the clients' consent for these conflicts. This heightened duty of loyalty is one of the foundational pillars of federal securities industry regulation.

Mr. Walsh describes this duty in the same words that were used to introduce the duty into the regulatory regime for U.S. securities markets. In addition, expert professional service is a service whose objective is to leads to long-term success. This success is defined as client's satisfaction and avoiding as well as eliminating defects to secure customer satisfaction.

\section{A Profession Should Be Aware of Its Status}

a. Mr. Walsh believes that "compliance satisfie[s] Justice Brandeis's definition of a profession." "Moreover, in these characteristics, we can see some of the professional standards that it should meet. The practice of compliance is an intellectual challenge that should be met through the exercise of expert judgment. Compliance should make sure the customer's interests, and the customer's perspective, are not forgotten.”

Mr. Walsh "disagree[d] with Justice Brandeis in one respect: The Justice's "definition is incomplete," Mr. Walsh said. "In addition to [the Justice's three elements,] a profession should be aware of its status." "To be truly professional, compliance's special status must be recognized by its practitioners, by those who employ them, and by the members of the public who deal with them. All should respect the public interest that fills this work. Earning compliance that recognition and respect is part of our mission." 36

b. The “dual-hatted" CLO/CCO Confidentiality Privilege. A senior research analyst, holding several securities licenses, traded ahead of the firm's clients on ten separate occasions over a two-month period. The analyst made a profit of $\$ 50,000$

\footnotetext{
${ }^{35} \mathrm{Id}$,

${ }^{36} I d$.
} 
on the trades. The "dual-hatted" LO/CO investigated the front-running allegations and concluded that the analyst did in fact engage in this conduct. The LO/CO recommended to the firm's management committee that the employee be asked to resign or be terminated. The management committee agreed with the recommendation, but the employee refused to resign and his service was subsequently terminated. In the U-5 filing required by the SEC to deregister the employee, the $\mathrm{LO} / \mathrm{CO}$ described "front-running" as the reason for termination.

The employee sued the firm for wrongful dismissal. During discovery, the LO/CO claimed that his discussions with others in the firm were subject to the attorneyclient privilege. The analyst objected and the court found that the $\mathrm{LO} / \mathrm{CO}$ had been acting as a compliance officer in that particular instance rather than as a lawyer. Therefore none of the LO/CO's conversations were privileged.

\section{What Type of People Are Compliance Officers?}

John Walsh suggests that compliance officers have the characteristics of entrepreneurs. ${ }^{37}$ They have the "what next" mentality. They are excited about change and interested in the unknown; perhaps because the unknown is where their opportunities lie. They are not afraid of what they do not know and are eager to learn. With continuous learning come recognizing problems and ideas for solutions. They focus on creating and implementing new ways of doing things. Often, they are more interested in the future than in the present or the past, particularly if the future promises better methods and results. This process and the ideas it brings, are the exciting for entrepreneurs. In this respect COs are similar to entrepreneurs. Also, like entrepreneurs, compliance personnel must be keenly aware of what is happening around them.

However, their objectives differ because COs' aim is prevention. However, the ways COs may achieve their purpose can be creative, and their awareness of changing reality leads to addressing the same problem in different ways. Trying a new method, or solution or anything new, does not ensure success, because there is no past to verify it.

\footnotetext{
${ }^{37}$ Id. Conclusion.
} 


\section{Conclusion}

The status of LOs and COs is a moving target. Therefore, this conclusion is a conclusive prediction. It seems that COs are here to stay, especially in large institutions. Their position and status are likely to rise. Institutions are likely to prefer internal COs to regulators' visits. However, the problem of large corporations' control of violations may not be resolved by COs, dedicated and professional as they might be. They will need increasingly the support and acceptance of management, at the board and at the divisional level. Corporate culture is a key to corporate legal activities. Hopefully both COs and LOs will contribute to a corporate culture that achieves successful competitive operations with legal constraints, a sense of the direction towards forbidden actions and prompt strong an action of stopping it in time. 